\title{
Immunohistochemical Analysis of 1.25-dihydroxyvitamin D3 Receptor Expression in Endometrial Cancer
}

\author{
Endometrium Kanserinde 1,25-dihidroksivitamin D3 Reseptör \\ Ekspresyonunun İmmünohistokimyasal Analizi
}

\author{
(D) Nesibe Kahraman Çetin11, (D Özgür Deniz Turan²
}

1Adnan Menderes University Faculty of Medicine, Department of Pathology, Aydın, Turkey

${ }^{2}$ Adnan Menderes University Faculty of Medicine, Department of Obstetrics and Gynecology, Aydın, Turkey

\section{Abstract}

Objective: This study aimed to immunohistochemically investigate the expression of 1.25-dihydroxyvitamin-D3-receptors (VDR) in benign and malignant lesions of the endometrial tissue.

Method: The cases were divided into two groups as benign $(n=10)$ and endometrioid adenocarcinoma $(n=17)$ according to their endometrial pathology results. The expression of VDR was examined by immunohistochemical method in endometrial tissues of participants $(n=27)$. Then, VDR expression levels were compared between the groups. The intensity of expression, extent of staining and overall scores were determined for the semi-quantitative evaluation of VDR expression. Demographic data of the patients were also recorded.

Results: There was no significant difference between the groups in terms of demographic data $(p>0.05)$ except age $(p<0.001)$. VDR expression level in the malignant group was significantly higher than in the benign group $(p<0.001)$. It was observed that when the tumor grade increased, the expression level of VDR also increased significantly $(r=0.888, p<0.001)$. Similarly, VDR expression increased significantly as the stage progressed $(r=0.639, p=0.006)$ but there was no statistically significant correlation between tumor size $(p=0.645)$, estrogen receptor positivity, PR positivity and presence of lymphovascular invasion on VDR expression ( $p>0.05$ ).

Conclusion: The expression of VDR was increased in endometrial cancer when compared to normal endometrial tissue. As the tumor behavior became aggressive, VDR expression also increased. As a result, increased VDR level may be associated with endometrial cancer development and stage of disease.

Keywords: Endometrial cancer, vitamin D, vitamin D receptor

\section{Öz} Amaç: Bu çalışma, endometrial dokunun benign ve malign lezyonlarında
1,25-dihidroksi-vitamin-D3-reseptörlerinin (VDR) ekspresyonunu
immünohistokimyasal olarak araştırmak için tasarlandı.

Yöntem: Olgular endometrial patoloji sonuçlarına göre benign $(n=10)$ ve endometrioid adenokarsinom $(n=17)$ olarak iki gruba ayrıldı. Olgulara $(n=27)$ ait olan endometrial dokulardaki VDR ekspresyonu immünohistokimyasal yöntemlerle incelendi ve gruplar arasında VDR ekspresyon seviyeleri karşılaştırıldı. VDR ekspresyonunun yarı nicel değerlendirilmesi için ekspresyon yoğunluğu, boyanma dansitesi ve genel skorlar belirlendi. Hastalara ait demografik veriler kaydedildi.

Bulgular: Gruplar arasında, yaş dışındaki $(p<0,001)$ demografik verilerde anlamlı fark yoktu $(p>0,05)$. Malign grupta VDR ekspresyon düzeyi benign gruba göre anlamlı olarak daha yüksekti $(p<0,001)$. Tümör derecesi arttığında VDR ekspresyon seviyesinin de önemli ölçüde arttığı gözlendi $(r=0,888, p<0,001)$. Benzer şekilde, VDR ekspresyonu da evre ilerledikçe önemli ölçüde artmıştı $(r=0,639, p=0,006)$. Ancak tümör boyutu, $(p=0,645)$, östrojen reseptörü pozitifliği, PR pozitifliği ve lenfovasküler invazyon varlığı ile VDR ekspresyonu arasında istatistiksel olarak anlamlı bir ilişki bulunamadı $(p>0,05)$.

Sonuç: VDR ekspresyonu, normal endometrial doku ile karşılaştıııldığında endometrial kanserde artmaktadır. Tümör davranışı agresif hale geldiğinde, VDR ekspresyonunun da arttığı gözlendi. Sonuç olarak, artan VDR seviyesi, endometrial kanser gelişimi ve hastalık evresi ile ilişkili olabilir.

Anahtar kelimeler: Endometrial kanser, vitamin D, vitamin D reseptörü

Address for Correspondence: Özgür Deniz Turan, Adnan Menderes University Faculty of Medicine, Department of Obstetrics and Gynecology, Aydın, Turkey

E-mail: ozgurdenizturan@gmail.com ORCID: orcid.org/0000-0003-2230-8404 Received: 01.01.2021 Accepted: 01.02.2021

Cite this article as: Kahraman Çetin N, Turan ÖD. Immunohistochemical Analysis of 1.25-dihydroxyvitamin D3 Receptor Expression in Endometrial Cancer. Bagcilar Med Bull 2021;6(2):142-147

๑C Copyright 2021 by the Health Sciences University Turkey, Bagcilar Training and Research Hospital Bagcilar Medical Bulletin published by Galenos Publishing House. 


\section{Introduction}

Endometrial cancer (EC) is the most common gynecological cancer in developed countries (1). Risk factors for EC are obesity, nulliparity, older age, unopposed estrogen therapy, and diabetes mellitus. There are two main subtypes of EC, known as endometrioid and non-endometrioid. Endometrioid type is well differentiated and estrogen dependent tumor seen at a younger age. In contrast, the non-endometrioid type (clear cell, serous) is known to be estrogen-independent and more aggressive tumors seen at older ages (2).

At the present times, low vitamin D levels are suggested as an important risk factor for many types of cancer. It has been reported that vitamin D may achieve its anti-carcinogenic effect via inhibition of cellular proliferation, enhancement of differentiation, apoptosis and modulation of calcium metabolism $(3,4)$. Besides the anti-carcinogenic properties of vitamin $\mathrm{D}$, it also has positive effects on cardiovascular disease and diabetes mellitus $(5,6)$.

Vitamin D active form (1.25-dihydroxyvitamin-D3) achieves all these effects via 1.25-dihydroxyvitamin-D3receptors (VDR). VDR belongs to the nuclear receptor group and is located on the long arm of the $12^{\text {th }}$ chromosome. VDR has been shown to be found in 30 different tissues in the body, including the endometrium. VDR is known to regulate gene expression by interacting with retinoic acid (RXR) transcription factor after combining with vitamin D active form $(7,8)$. A recent study has reported that the RXR receptor and VDR are overexpressed in mutation of BRCA1 in breast cancer cases and predicted overall survival (9). VDR expression has been demonstrated in many types of cancer, including EC. This situation strengthens the possibility of VDR to play a role in cancer etiology (10). Since studies investigating the relationship between EC and VDR are quite limited in the literature $(11,12)$, we aimed to investigate the vitamin D receptor expression in EC cells in the present study.

\section{Materials and Methods}

Tissue samples were obtained from İstanbul University Cerrahpaşa-Cerrahpaşa Pathology Laboratory between January 2017 and January 2018. Demographic data of the patients were recorded. The cases were divided into two groups as benign $(\mathrm{n}=10)$ and endometrioid adenocarcinoma ( $n=17$ ) according to their endometrial pathology results. The expression of VDR was immunohistochemically (IHC) investigated in endometrial tissues of participants $(n=27)$ and VDR expression levels were compared between the groups. The intensity of expression, staining density and overall scores were determined for the semi-quantitative evaluation of VDR expression.

The material was archival formalin-fixed, paraffinembedded tissue from routine histopathological work-ups. Tumor blocks of paraffin-embedded tissue were selected by experienced pathologist, evaluating the routine H\&E stained sections. Tissue samples used for immunohistochemistry were proliferative and secretory phase endometrium and endometrioid adenocarcinoma

\section{IHC Analysis}

The immunostaining was carried out at the room temperature using DAKO Autostainer Universal Staining System (Autostainer Link 48 DAKO, Glostrup, Denmark). At the first step, sections obtained from selected paraffin embedded blocks in 4-mm thickness were put on positively charged slides. Then, all the sections were deparaffinized in xylene and dehydrated through a graded series of ethanol solution. At the third stage, antigen retrieval was performed at $96{ }^{\circ} \mathrm{C}(10 \mathrm{mM} / \mathrm{L}$ citrate buffer, $\mathrm{pH}$ 6) for $40 \mathrm{~min}$ in a thermostatic bath (PT link). The sections were incubated with anti-GC (primary VDR antibody cat. no: \#12550, Cell signaling technology, inc. dilution of 1:200) for $60 \mathrm{~min}$ at the room temperature. Positive and negative controls were added for antibody. A streptavidin-biotin enhanced immunoperoxidase technique (K8000 Envision Flex, DAKO, Glostrup, Denmark) in an automated system was used to show immunoreactions. The sections were incubated with $\mathrm{DAB}$ and counterstained lightly with hematoxylin to demonstrate binding. Finally, the sections were dehydrated and mounted onto the slides. The positively immunostained slides were used as positive controls. Normal rabbit serum IgG was used to replace primary antibody as a negative control.

\section{Evaluation of the Immunostaining}

All the sections were examined under light microscope (Olympus BX53 Olympus Co., Tokyo, Japan). Image Analysis Software (DP-BSW Microscope digital camera software program) was used for assessing the samples. For each section, five areas of similar grade were analyzed semiquantitatively for the fraction of cells staining. The intensity of VDR expression evaluated microscopically was graded on a scale of 0 to $3+(0$, no staining; $1+$, mildly intense; $2+$, moderately intense; $3+$, severely intense). The extent of staining was quantified as the percentage of cells staining positive for VDR antibody, as follows: $0=$ no 
staining; $1=$ positive staining in $<25 \%$ of the sample; $2=$ positive staining in $25 \%-50 \%$ of the sample; $3=$ positive staining in $>50 \%$ of the sample. Intensity score (0 to $3+$ ) was multiplied by the density score $(0-3)$ to give an overall score of 0-9. The overall score for each specimen was then categorically assigned to one of the following groups: 0 score, negative expression; 1-2 scores, weak expression; 3-6 scores, moderate expression; 7-9 score, strong expression (Table 1) (13).

\section{Statistical Analysis}

Whether the distributions of continuous variables were normal or not was determined with the Shapiro-Wilk test. The assumption of homogeneity of variances was examined by the Levene test. Descriptive statistics were expressed as mean \pm standard deviation, median (minimum-maximum) or number of cases and (\%), where appropriate. While the mean differences between the groups were compared using the Student's t-test, the Mann-Whitney U test was applied for the comparisons of the variables which did not meet the parametrical test assumptions. In both $2 \mathrm{x} 2$ and also $\mathrm{RxC}$ contingency tables to compare categorical variables, the Fisher's Exact or Fisher Freeman Halton test was used when $1 / 4$ or more of the cells had an expected frequency of 5 or less. Spearman's rank order correlation coefficients were calculated to determine degrees of association between tumor size, tumor grade, and stage with overall expression scores. Data analysis was performed using IBM SPSS Statistics version 17.0 software (IBM Corporation, Armonk, NY, USA). A p-value less than 0.05 was considered as statistically significant.

\section{Results}

Comparisons of demographic and clinical characteristics of benign (control) and malignant (study) groups are shown in Table 2. The mean age of the case group was statistically significantly higher than that of the control group $(p<0.001)$. Among the groups, there was no statistically significant

\begin{tabular}{|c|c|c|c|}
\hline Score & $\begin{array}{l}\text { Intensity } \\
\text { expression (X) }\end{array}$ & $\begin{array}{l}\text { Staining } \\
\text { density }(Y)\end{array}$ & $\begin{array}{l}\text { Overall score } \\
(\mathrm{XxY})\end{array}$ \\
\hline 0 & No staining & No staining & Negative expression \\
\hline+1 & Mildly intense & $\begin{array}{l}<25 \% \text { of the } \\
\text { sample }\end{array}$ & 1-2: weak expression \\
\hline+2 & $\begin{array}{l}\text { Moderately } \\
\text { intense }\end{array}$ & $\begin{array}{l}25-50 \% \text { of the } \\
\text { sample }\end{array}$ & $\begin{array}{l}\text { 3-6: moderate } \\
\text { expression }\end{array}$ \\
\hline+3 & Severely intense & $\begin{array}{l}>50 \% \text { of the } \\
\text { sample }\end{array}$ & $\begin{array}{l}\text { 7-9: strong } \\
\text { expression }\end{array}$ \\
\hline
\end{tabular}

difference in terms of body mass index, parity, education level, hypertension, diabetes mellitus and smoking history ( $>0.05$ ).

Other clinical parameters of endometrioid cancer cases are shown in Table 3.

The intensity, extent of staining and overall median expression scores of the study group were statistically significantly higher than those of the control group $(\mathrm{p}=0.005, \mathrm{p}<0.001$ and $\mathrm{p}<0.001)$ (Figure 1$).$

Table 3 shows the correlation levels between tumor grade, tumor diameter and stage and overall staining score within the study group. Accordingly, as the tumor grade increased, the overall expression score increased significantly $(r=0.888$,

\begin{tabular}{llll}
\multicolumn{4}{c}{ Table 2. Demographic and clinical data of the groups } \\
& $\begin{array}{l}\text { Control } \\
\text { group } \\
(\mathbf{n}=10)\end{array}$ & $\begin{array}{l}\text { Study } \\
\text { group } \\
(\mathbf{n}=17)\end{array}$ & p \\
\hline Age (year) & $48.0 \pm 4.0$ & $58.9 \pm 7.4$ & $<0.001^{\dagger}$ \\
BMI (kg/m $\left.{ }^{2}\right)$ & $27.2 \pm 4.0$ & $29.6 \pm 5.6$ & $0.253 \dagger$ \\
Parity & $3(2-5)$ & $2(0-5)$ & $0.287 \ddagger$ \\
Education & - & - & $0.773^{q}$ \\
Primary school & $9(90.0 \%)$ & $13(76.5 \%)$ & - \\
High school & $1(10.0 \%)$ & $2(11.8 \%)$ & - \\
University & $0(0.0 \%)$ & $2(11.8 \%)$ & - \\
Hypertension & $4(40.0 \%)$ & $9(52.9 \%)$ & $0.695^{\ddagger}$ \\
Diabetes mellitus & $3(30.0 \%)$ & $8(47.1 \%)$ & $0.448^{\ddagger}$ \\
History of smoking & $2(20.0 \%)$ & $4(23.5 \%)$ & $>0.999^{*}$ \\
Intensity expression scores & $1(1-3)$ & $2(1-3)$ & $0.005^{\ddagger}$ \\
Staining density scores & $1(0-1)$ & $2(1-3)$ & $<0.001^{\ddagger}$ \\
Overall scores & $1(0-2)$ & $4(1-9)$ & $<0.001^{\ddagger}$ \\
\hline
\end{tabular}

'Student's t-test, ${ }^{\ddagger}$ Mann-Whitney $U$ test, "Fisher-Freeman-Halton test, ¥Fisher's Exact test, BMI: Body mass index

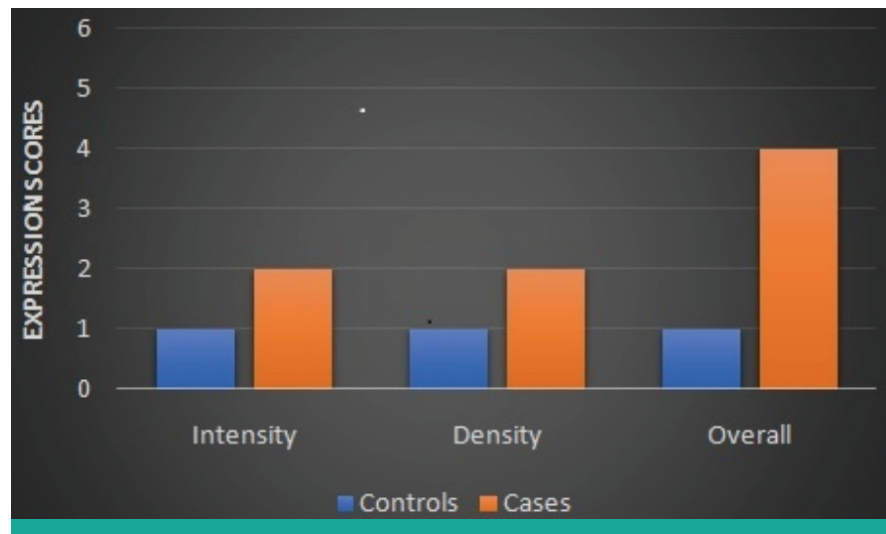

Figure 1. The distribution of VDR expression scores (intensity, density and overall) in the endometrial tissue according to the groups

VDR: 1.25-dihydroxyvitamin-D3-receptors 
$\mathrm{p}<0.001)$. While there was no statistically significant correlation between tumor diameter and overall expression $(\mathrm{p}=0.645)$, as the stage progressed, the overall expression score also increased significantly $(\mathrm{r}=0.639, \mathrm{p}=0.006)$.

\begin{tabular}{|c|c|}
\hline & $n=17$ \\
\hline \multicolumn{2}{|l|}{ Grade of tumor } \\
\hline I & $6(35.3 \%)$ \\
\hline II & $8(47.1 \%)$ \\
\hline III & $3(17.6 \%)$ \\
\hline Tumor diameter (cm) & $3.5(0.5-5.0)$ \\
\hline ER + & $10(58.8 \%)$ \\
\hline PR + & $10(58.8 \%)$ \\
\hline \multicolumn{2}{|l|}{ Myometrial invasion } \\
\hline Less than $1 / 2$ & $14(82.4 \%)$ \\
\hline More than $1 / 2$ & $3(17.6 \%)$ \\
\hline Lymphovascular invasion & $4(23.5 \%)$ \\
\hline \multicolumn{2}{|l|}{ Intraperitoneal fluid } \\
\hline Benign & $14(93.3 \%)$ \\
\hline Malignant & $1(6.7 \%)$ \\
\hline \multicolumn{2}{|l|}{ Stage } \\
\hline A1 & $13(76.5 \%)$ \\
\hline B1 & $1(5.9 \%)$ \\
\hline B2 & $2(11.8 \%)$ \\
\hline 4 & $1(5.9 \%)$ \\
\hline
\end{tabular}

ER: Estrogen receptor, PR: Progesterone receptor
In Table 4, the comparisons made in terms of overall staining scores according to the other clinical findings of the cases within the case group are included. Accordingly, there was no statistically significant effect of ER positivity, PR positivity and LVI on overall expression scores $(p>0.05)$. On the other hand, overall staining scores of those with more than $1 / 2$ were statistically significantly higher than those with myometrial invasion level less than $1 / 2(p=0.012)$.

\section{IHC Results of the VDR \\ VDR Expression in Normal Endometrium}

The VDR immunoreactivity in the proliferative and secretory phase endometrium was weak nuclear staining in the glandular epithelium compared to the surrounding stroma. Some of the normal endometrial glands revealed weak nuclear immunoreactivity for VDR, while the remaining cases were VDR negative (Figure 2).

\section{VDR Expression in Endometrioid Adenocarcinoma}

The VDR immunostaining of an endometrioid adenocarcinoma revealed moderate-strong immunostaining of endometrial cells. The intensity of VDR immunostaining and the number of VDR positive cells were both up-regulated in endometrioid adenocarcinoma cells as compared to control endometrium. In respect of the vitamin D receptor in grade III endometrioid adenocarcinoma, its expression was more increased compared to normal endometrial glands. It

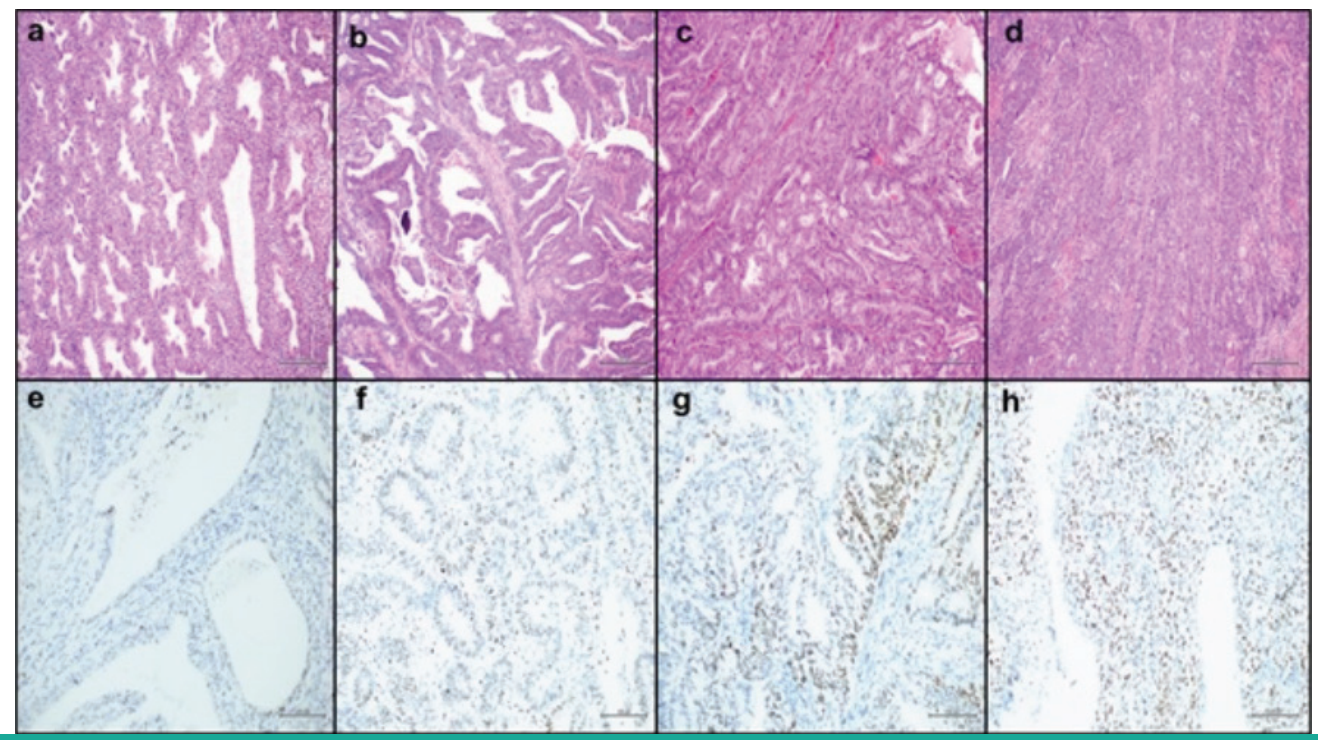

Figure 2. Expression of VDR in normal endometrial tissue and endometrioid adenocarcinoma. H-E staining (a,b,c,d) and immunohistochemical VDR expression (e,f,g,h) in normal endometrial tissue (a,e), grade I (b,f), grade II (c,g) and grade III (d,h). Original magnification of H-E and VDR immunostaining at x200 (scale bar $100 \mu \mathrm{m}$ ). Notice strong immunoreactivity for VDR that is upregulated in grade III endometrioid adenocarcinoma compared to normal endometrial tissue 
was shown that the VDR immunoreactivity was upregulated in cancer cells (Figure 2).

\section{Discussion}

Currently, the relationship between vitamin D and cancers is being studied more. However, most of these studies consist of epidemiological studies $(13,14)$. Although the relationship between vitamin $\mathrm{D}$ and many cancer types has been shown, the studies on the relationship between EC and vitamin D are quite limited in the literature. In an ecological study, it was shown that ultraviolet-B decreased the incidence of EC by increasing vitamin D level. On the contrary, it was emphasized in a meta-analysis that no significant relationship was found between vitamin D intake and EC. These conflicting and limited results suggest that this issue should be investigated further.

Studies on vitamin D receptors at the tissue receptor level are very limited in the literature, especially in EC $(11,12)$. Therefore, we chose to investigate vitamin D receptor expression in EC tissue.

In the systematic review by Deuster et al. (10), it was reported that VDR expression increased in all gynecological cancers. In addition, it was reported that $V D R$ gene polymorphism was associated with increased risk of breast, prostate, and bowel cancer in studies other than gynecological cancers (15-17). This information supports the possibility that VDR may play a role in the development of EC.

It is known that estrogen is an important risk factor in the development of EC (2). It was reported in a previous study that VDR was a mediator of estrogen-dependent pathways (18). In our study, there was no statistically significant effect of ER positivity and PR positivity on overall expression scores $(p>0.05)$ in endometrioid adenocancer cases. We think that further studies at molecular level are needed in the future regarding the relationship between estrogen and VDR.

Table 4. Correlation coefficients and significance levels between tumor grade, tumor diameter and stage and overall staining score within the study group

\begin{tabular}{lll} 
& Correlation coefficients & $\mathbf{p}^{\dagger}$ \\
\hline Tumor grade & 0.888 & $<0.001$ \\
Tumor diameter & -0.121 & 0.645 \\
Stage & 0.639 & $\mathbf{0 . 0 0 6}$ \\
\hline
\end{tabular}

†Spearman's rank order correlation analysis
There were very few studies in the literature similar to our study. In the study conducted by Agic et al. (11) in only five EC cases, VDR expression was found to be higher in the EC group compared to the benign group. These findings were not compatible with those of Bergada et al. (12). Yabushita et al. (19) observed that VDR expression decreased when 1.25 dihydroxyvitamin D3 was added to EC live cell cultures for six days. In our study, VDR expression was found to be higher in the EC group ( $\mathrm{n}=17)$ compared to the benign group. This situation may be explained by the increase in VDR due to low vitamin D level in EC. Since our study was designed retrospectively, serum vitamin $\mathrm{D}$ levels could not be measured simultaneously.

In our study, in accordance with the findings of Bergada et al. (12), it was observed that VDR expression increased significantly as the grade of tumor tissue increased in EC cases $(\mathrm{r}=0.888, \mathrm{p}<0.001)$. In addition, as the stage progressed, the overall expression score also increased statistically significantly $(\mathrm{r}=0.639, \mathrm{p}=0.006)$ but there was no statistically significant correlation between tumor diameter and overall expression $(\mathrm{p}=0.645)$. Similarly, overall staining scores of those with more than $1 / 2$ were statistically significantly higher than those with myometrial invasion level less than $1 / 2(p=0.012)$. This indicates that VDR expression increases as the tumor grade and stage increases. There was information that VDR expression increased as vitamin D level decreased. (19). VDR is a nuclear receptor and it is not clear how to work. In a molecular study on VDR, it was reported that VDR interacts with transcription factors such as RXR and exerts its anticarcinogenic effects by regulating gene expression (8). In this way, it may be possible for VDR to affect grade and stage of tumors.

There was no significant difference in demographic data except age. This difference may be related to the fact that EC cases are seen at older ages. Moreover, simultaneous serum vitamin D levels could not be measured because our study was not designed prospectively. In addition, the inhomogeneity of the number of the groups, low number of cases and not investigating the relationship between histological subtypes and VDR expression can be counted among the limitations of this study.

\section{Conclusion}

As a result, increased VDR expression in endometrial tissue may be closely related to the development of EC. Prospective studies are needed on this subject. 


\section{Ethics}

Ethics Committee Approval: The study protocol was approved by the local ethics committee of our institution (09/12/2020-E.63807).

Informed Consent: Written informed consent was obtained.

Peer-review: Internally peer-reviewed.

\section{Authorship Contributions}

Concept: Ö.D.T., N.K.Ç., Design: Ö.D.T., N.K.Ç., Data Collection or Processing: Ö.D.T., N.K.Ç., Literature Search: Ö.D.T., N.K.Ç., Analysis or Interpretation: Ö.D.T., N.K.Ç., Writing: Ö.D.T., N.K.Ç.

Conflict of Interest: No conflict of interest was declared by the authors.

Financial Disclosure: The authors declared that this study has received no financial support.

\section{References}

1. Stewart BW, Wild C. World cancer report: Cancer Worldwide. 3rd ed. Lyon, France: Non-Series Publications; 2014:12-18.

2. Purdie DM, Green AC. Epidemiology of endometrial cancer. Best Pract Res Clin Obstet Gynaecol 2001;15(3):341-354.

3. Miettinen S, Ahonen MH, Lou YR, Manninen T, Tuohimaa P, Syvala $\mathrm{H}$, et al. Role of 24-hydroxylase in vitamin D3 growth response of OVCAR-3 ovarian cancer cells. Int J Cancer 2004;108(3):367-373.

4. Ziegler RG, Jones CJ, Brinton LA, Norman SA, Mallin K, Levine $\mathrm{RS}$, et al. Diet and the risk of in situ cervical cancer among white women in the United States. Cancer Causes Control 1991;2(1):1729.

5. Garland CF, Garland FC, Gorham ED, Lipkin M, Newmark H, Mohr $\mathrm{SB}$, et al. The role of vitamin D in cancer prevention. Am J Public Health 2006;96(2):252-261.

6. Pittas AG, Chung M, Trikalinos T, Joanna Mitri J, Brendel M, Patel K, et al. Systematic review: Vitamin $\mathrm{D}$ and cardiometabolic outcomes. Ann Intern Med 2010;152(5):307-314.

7. Kim JS, Kim YI, Song C, Yoon I, Park JW, Choi YB, et al. Association of vitamin D receptor gene polymorphism and Parkinson's disease in koreans. J Korean Med Sci 2005;20(3):495-498.
8. Zhang J, Chalmers MJ, Stayrook KR, Burris LL, Wang Y, Busby SA, et al. DNA binding alters coactivator interaction surfaces of the intact vdr-rxr complex. Nat Struct Mol Biol 2011;18(5):556-563.

9. Ferlay J, Soerjomataram I, Dikshit R, Eser S, Mathers C, Rebelo $\mathrm{M}$, et al. Cancer incidence and mortality worldwide: Sources, methods and major patterns in globocan 2012. Int J Cancer 2015;136(5):E359-E386.

10. Deuster E, Jeschke U, Ye Y, Mahner S, Czogalla B. Vitamin D and VDR in gynecological cancers - a systematic review. Int J Mol Sci 2017;18(11):2328.

11. Agic A, Xu H, Altgassen C, Noack F, Monika M, Wolfler MM, et al. Relative expression of 1,25-dihydroxyvitamin d3 receptor,vitamin d $1 \alpha$-hydroxylase, vitamin d 24- hydroxylase, and vitamin d 25-hydroxylase in endometriosis and gynecologic cancers. Reprod Sci 2007;14(5):486-497.

12. Bergada L, Pallares J, Arcidiacono MV, Cardus A, Santacana M, Valls J, et al. Role of local bioactivation of vitamin D by CYP27Al and CYP2R1 in the control of cell growth in normal endometrium and endometrial carcinoma. Lab Invest 2014;94(6):608-622.

13. Zhigang Z, Wenlv S. Prostate stem cell antigen (PSCA) expression in human prostate cancer tissues: implications for prostate carcinogenesis and progression of prostate cancer. Jpn J Clin Oncol 2004;34(7):414-419.

14. Mohr SB, Garland CF, Gorham ED, Grant WB, Garland FC. Is ultraviolet $\mathrm{b}$ irradiance inversely associated with incidence rates of endometrial cancer: An ecological study of 107 countries. Prev Med 2007;45(5):327-331.

15. McCullough ML, Bandera EV, Moore DF, Kushi LH. Vitamin D and calcium intake in relation to risk of endometrial cancer: A systematic review of the literature. Prev Med 2008;46(4):298-302.

16. Taylor JA, Hirvonen A, Watson M, Pittman G, Mohler JL, Bell DA. Association of prostate cancer with vitamin D receptor gene polymorphism. Cancer Res1996;56(18):4108-4110.

17. Lowe LC, Guy M, Mansi JL, Peckitt C, Bliss J, Colston KW. Plasma 25-hydroxy vitamin D concentrations, vitamin $\mathrm{D}$ receptor genotype and breast cancer risk in a UK Caucasian population. Eur J Cancer 2005;41(8):1164-1169.

18. Ingles SA, Wang J, Coetzee GA, Lee ER, Frankl HD, Haile RW. Vitamin D receptor polymorphisms and risk of colorectal adenomas (United States). Cancer Causes Control 2001;12(7):607614.

19. Yabushita H, Hirata M, Noguchi M, Nakanishi M. Vitamin D receptor in endometrial carcinoma and the differentiationinducing effect of 1,25-dihydroxyvitamin D3 on endometrial carcinoma cell lines J Obstet Gynaecol Res 1996;22(6):529-539. 